\title{
The State of Academia in Puerto Rico After Hurricane María
}

\author{
Luis A. Medina
}

September 20, 2017, is a day that marked change in the life of every resident of Puerto Rico. Around 6:15 am, local time, Hurricane María made landfall. María was a powerful high-end Category 4 hurricane packing sustained winds of $155 \mathrm{mph}$. It is the strongest hurricane to hit Puerto Rico since hurricane San Felipe II hit the archipelago with sustained winds of $160 \mathrm{mph}$ in 1928. centers had power generators, but they needed diesel fuel, which became scarce. The Governor's office estimates the cost of the storm to be US $\$ 94.4$ billion. Recovery has been slow and there is still much work that needs to be done. The sense of isolation and crisis was exacerbated by the shared feeling of most Puerto Ricans that the US government's emergency response was slow and inadequate [1].
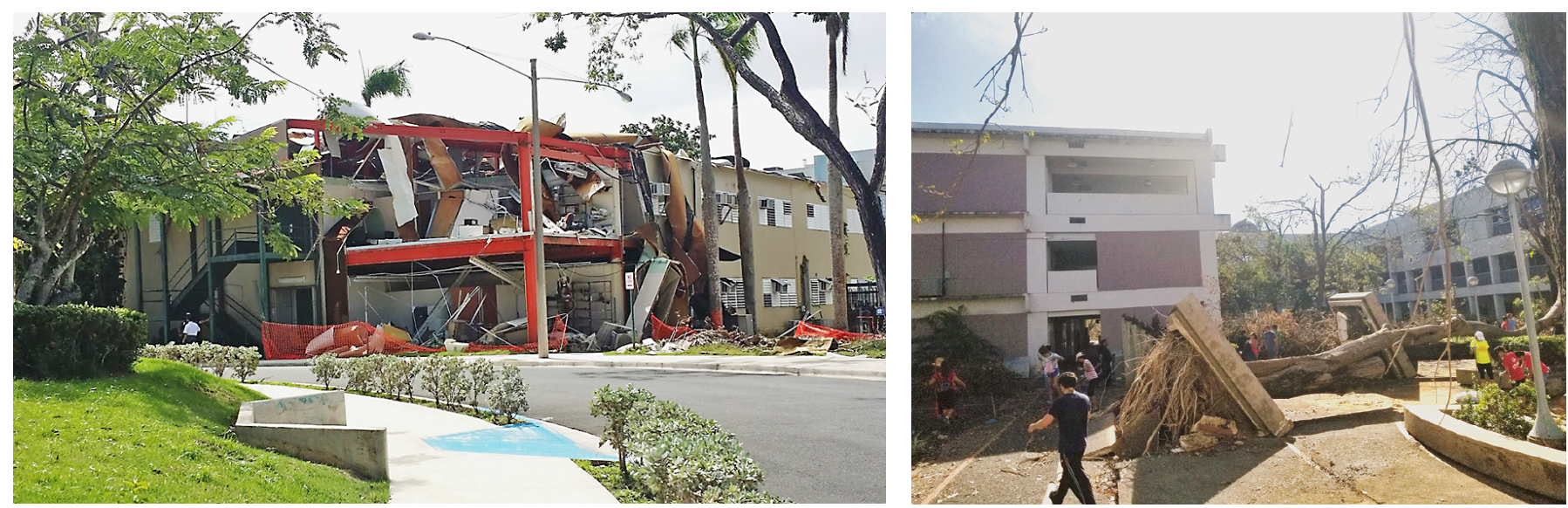

Figure 1. Left: Facundo Bueso Anex building, UPR-Río Piedras was demolished by Hurricane María. Right: Students, faculty, and staff remove debris from the campus.

The catastrophic storm caused a humanitarian crisis from which Puerto Rico is still recovering one year later. No town or city was spared. The storm destroyed many houses, dismantled telecommunication towers, and obliterated the entire island's electrical grid. Potable water quickly became non-existent. Many people lost their lives in hospitals and care centers because no power meant no dialysis, no oxygen, and worse. Most hospitals and care

Luis A. Medina is associate professor of mathematics at the University of Puerto Rico at Río Piedras. His email address is 1uis.medina17@upr.edu.

For permission to reprint this article, please contact: reprint-permission@ams.org.

DOI: http://dx.doi.org/10.1090/noti1715
The crisis greatly affected academia. The infrastructure of every university in Puerto Rico suffered. Some science laboratories, classrooms, and other facilities were destroyed (see Figure 1). A preliminary assessment estimates the losses in infrastructure to the public university alone at US\$118 million dollars [2].

The fall semester was halted for every university on the island. When the semester resumed, many students were displaced and power was unavailable. Some classes were being offered in tents, but students had limited time to study, as there was no electrical power at home, and every academic activity needed to end at 5:00 pm when daylight turned to dusk. Professors needed to design examinations that took into account the students' difficulties. Nevertheless, we all welcomed the re-opening of our university 
and were determined to make it work. Many students, professors, and employees volunteered to remove debris and clean the campuses. Many US universities offered tuition-free registration for Puerto Ricans affected by the storm. We in Puerto Rico are very grateful for that gesture.

Most mathematical research coming from Puerto Rico was put on hold right after María. Part of the problem can be traced back to the lack of internet; however, the bulk of the problem can be attributed to the difficult living conditions. Planning for the next hot meal, finding a store with ice available to keep medicine cold, and standing in line for hours to get gasoline or cash were the top priorities for most residents of Puerto Rico.

More than six months after María's wrath, there were still problems to contend with. Some of those problems could be attributed to the instability of the electrical grid and to the overall slow pace of recovery. Others related to what already was an anemic economy. Internet is not as reliable as it used to be. Printing exams can be an odyssey. Deadlines for grant proposals need to be treated with extra care. But we learned to plan things well in advance to ensure that work was not compromised by a sudden power outage or internet failure. Our university is now once again operational. Our students are coming. We are exchanging ideas, solidifying knowledge, and working on our research projects.

As we continue to recover from María, we find ourselves preparing for the onslaught from a storm of a different sort: financial crisis. The causes and effects of this crisis present us with a challenge perhaps greater than that presented by María, with long-lived consequences for our public institutions. Part of this new challenge is the out-migration of young Puerto Ricans. Jens Manuel Krogstad, an editor at the Pew Research Center, was quoted on CNN . com in February 2018 as stating that "It sounds possible that we're on pace for a historic net out-migration to the US from Puerto Rico. In 2015, the net out-migration was about 64,000 people...it sounds like it's possible that even after just a few months we're already on pace to overshoot that."

Our island population's steady decline over the past fourteen years is only part of the new challenges facing Puerto Rico. A shrinking population translates into a smaller tax base, which in turn places a greater strain on already overstretched government resources. The Financial Oversight and Management Board for Puerto Rico and the local government have recently made proposals for severe budget cuts to our academic institutions. These proposals have the potential to not only alter our university's mission but also to put all research in peril. We do not know how much different the university is going to be in the coming years. We hope that we can combat this new challenge, that Puerto Rico will see its way through this storm to job creation that will lead to economic growth and an eventual reversal in the population decline. In the face of it all, we in academia are determined to continue doing our work. Enlivening our universities. Making new plans. Exchanging ideas. Solidifying knowledge. Pursuing necessary research.

\section{References}

[1] LAIgNEE BARRON. US Emergency Response Efforts in Puerto Rico Aren't Good Enough, UN Experts Say. time.com/5003470/ united-nations-puerto-rico-hurricane-response.

[2] MARÍA SOLEDAD DÁvILA CALERO. Ascienden a \$118 millones los daños en recintos de la UPR. CB en Español, local newspaper, San Juan. Wednesday, October 25, 2017.

\section{Photo Credits}

Figure 1, right, courtesy of Dr. José R. Ortiz.

All other article photos courtesy of Luis A. Medina.

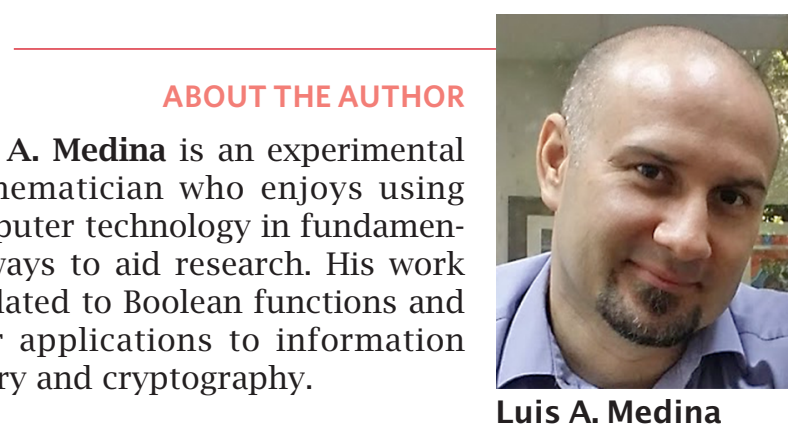

